\title{
KESENJANGAN ANGGARAN PADA BELANJA DAERAH PROVINSI
}

\author{
Yudanto \\ Direktorat Jenderal Anggaran \\ Kuwat \\ PKN STAN \\ Alamat Korespondensi: kuwatslamet@pknstan.ac.id
}

\section{INFORMASI ARTIKEL}

Diterima Pertama

07 Juni 2018

Dinyatakan Diterima

06 Desember 2018

KEY WORDS:

budgetary slack, budgetary growth, budgetary participation, asymmetric information.

\section{KATA KUNCI:}

kesenjangan anggaran, pertumbuhan anggaran, partisipasi anggaran, informasi asimetris.

KLASIFIKASI JEL:

H720 State and Local Budget and Expenditures

\begin{abstract}
ABSTRAK
This research aims to examine the effect of budgetary growth, budgetary participation, and asymmetric information on budgetary slack in the regional expenditure budget in Indonesia, either partially or simultaneously. The research object is the amount of regional expenditures budget and realization of 33 provinces in Indonesia for period 2008-2016. In this research, budgetary growth is measured in percentage by the difference between the certain year budget and the previous one. Furthermore, budgetary participation is measured by the size of the personnel budget and asymmetric information is measured by the amount of budget allocated in each province. The statistical method used in this research is parametric statistical inferential by using multiple regression analysis. The results showed that partially both budgetary growth and budgetary participation did not affect the budgetary slack significantly, while asymmetric information had significant influence. However, simultaneously these three variables have significant effect on the budgetary slack. Therefore, it can be concluded that actually there is a phenomenon of budgetary slack in the regional expenditure budget in Indonesia for period 20082016. This phenomenon is influenced simultaneously by the budgetary growth, budgetary participation, and asymmetric information that explaining the phenomenon of the budgetary slack for $72.7 \%$.
\end{abstract}

Penelitian ini bertujuan untuk menguji pengaruh pertumbuhan anggaran, partisipasi anggaran, dan informasi asimetris terhadap kesenjangan anggaran dalam anggaran belanja daerah di Indonesia, baik secara parsial maupun bersama-sama. Objek penelitian berupa besaran anggaran dan realisasi belanja daerah pada 33 provinsi dalam kurun waktu 2008-2016. Dalam penelitian ini, pertumbuhan anggaran diukur melalui selisih antara pagu anggaran belanja daerah dalam tahun tertentu yang dibandingkan dengan tahun sebelumnya dalam satuan persentase. Sementara itu, partisipasi anggaran diukur dengan menggunakan besaran anggaran belanja pegawai pada tiap-tiap provinsi dan informasi asimetris diukur dengan menggunakan besaran anggaran belanja yang dialokasikan pada tiap-tiap provinsi. Metode statistika yang digunakan dalam penelitian ini adalah statistika inferensia parametrik dengan menggunakan analisis regresi berganda. Hasil penelitian menunjukkan bahwa secara parsial pertumbuhan anggaran maupun partisipasi anggaran tidak berpengaruh secara signifikan terhadap 
kesenjangan anggaran, sedangkan informasi asimetris berpengaruh secara signifikan terhadap kesenjangan anggaran. Namun demikian, secara simultan ketiga variabel tersebut berpengaruh signifikan terhadap kesenjangan anggaran. Oleh karena itu, dapat disimpulkan bahwa sesungguhnya terjadi fenomena kesenjangan anggaran atau budgetary slack pada anggaran belanja pemerintah daerah pada kurun waktu 20082016. Fenomena ini dipengaruhi secara bersama-sama oleh pertumbuhan anggaran, partisipasi anggaran, dan informasi asimetris yang mampu menjelaskan fenomena kesenjangan anggaran yang terjadi sebesar $72,7 \%$. 


\section{PENDAHULUAN}

\subsection{Latar Belakang}

Pemerintah daerah merupakan bagian yang tidak terpisahkan dengan pemerintah pusat dalam suatu negara. Pada tahun 2017, terdapat 34 pemerintahan provinsi dan 514 pemerintahan kabupaten/kota di Indonesia. Undang-Undang (UU) Nomor 32 Tahun 2004 tentang Pemerintahan Daerah menyebutkan bahwa setiap Pemerintah Provinsi maupun Pemerintah Kabupaten/Kota memiliki hak, wewenang, dan kewajiban daerah untuk mengatur dan mengurus sendiri urusan pemerintahan dan kepentingan masyarakat setempat di daerahnya.

Adanya desentralisasi tersebut tidak membuat pemerintah pusat serta merta bersikap lepas tangan dari urusan kedaerahan. Sebagai daerah otonom, pemerintah daerah masih diberikan bantuan dari pemerintah pusat berupa dana perimbangan yang dapat digunakan untuk pelaksanaan kegiatan dalam rangka pembangunan daerah.

Pemerintah menetapkan UU Nomor 33 Tahun 2004 tentang Perimbangan Keuangan sebagai peraturan lanjutan dari UU Nomor 32 Tahun 2004 tentang Pemerintahan Daerah yang telah ditetapkan sebelumnya. Berdasarkan definisi dalam UU Nomor 33 Tahun 2004, perimbangan keuangan antara pemerintah pusat dan pemerintah daerah adalah suatu sistem pembagian keuangan yang adil, proporsional, demokratis, transparan, dan efisien dalam rangka pendanaan penyelenggaraan desentralisasi, dengan mempertimbangkan potensi, kondisi, dan kebutuhan daerah, serta besaran pendanaan penyelenggaraan dekonsentrasi dan tugas pembantuan.

Menurut Yuwono dalam penelitian Siagian (2009), Anggaran Pendapatan dan Belanja Daerah (APBD) adalah suatu rencana keuangan tahunan daerah yang ditetapkan berdasarkan peraturan daerah yang disetujui oleh Dewan Perwakilan Rakyat Daerah (DPRD). Sementara itu, APBD didefinisikan dalam UU Nomor 33 Tahun 2004 sebagai rencana keuangan tahunan pemerintahan daerah yang dibahas dan disetujui bersama oleh pemerintah daerah dan DPRD, dan ditetapkan dengan Peraturan Daerah.

Keuangan daerah menampung jumlah anggaran daerah yang terdiri dari anggaran pendapatan daerah maupun anggaran belanja daerah. Anggaran pendapatan daerah merupakan estimasi pendapatan yang akan diperoleh oleh pemerintah daerah dalam suatu periode anggaran. Sementara itu, anggaran belanja daerah adalah estimasi belanja yang akan dikeluarkan oleh pemerintah daerah untuk melakukan atau memperoleh sesuatu dalam periode anggaran tertentu.

Anggaran belanja setiap daerah dalam APBD memiliki jumlah yang relatif meningkat setiap tahunnya. Sebagai gambaran tentang kondisi keuangan suatu daerah provinsi, pada Gambar 1 disajikan anggaran belanja dan realisasi belanja pemerintah provinsi yang berada di Pulau Jawa, yang merupakan pulau dengan kepadatan tertinggi dan jumlah anggaran terbesar di Indonesia, untuk kurun waktu 4 tahun yaitu tahun 2013 s.d. 2016. Di pulau ini, terdapat 6 pemerintah provinsi, yaitu Provinsi Daerah Khusus Ibukota (DKI) Jakarta, Provinsi Jawa Barat, Provinsi Jawa Tengah, Provinsi Daerah Istimewa Yogyakarta (DIY), Provinsi Jawa Timur, dan Provinsi Banten. Selama 4 tahun tersebut, jumlah anggaran yang dialokasikan pada seluruh pemerintah provinsi di Pulau ini relatif meningkat setiap tahunnya. Pada tahun 2013 anggaran belanja daerah berjumlah Rp99,686 triliun, sedangkan pada tahun 2016 anggaran tersebut meningkat menjadi Rp147,026 triliun.

Namun demikian, peningkatan anggaran belanja tersebut ternyata tidak didukung oleh pelaksanaan realisasi belanja yang baik. Artinya, dengan anggaran yang lebih besar, masih terdapat pula anggaran yang tidak terrealisasikan oleh pemerintah daerah. Hal ini nampak pada selalu adanya selisih antara anggaran belanja dan realisasi belanja di setiap tahunnya.

\section{Gambar 1: Selisih Realisasi dan Anggaran Belanja Pemerintah Provinsi di Pulau Jawa}

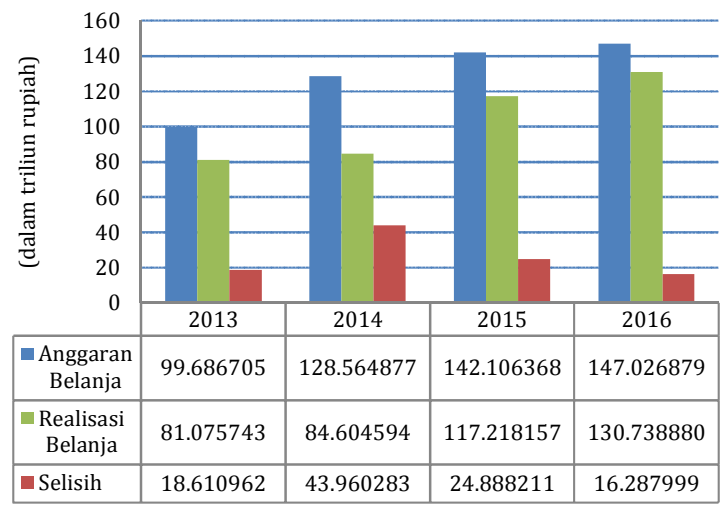

Sumber: Diolah dari Direktorat Perimbangan Keuangan

Gambar 1 menunjukkan adanya perbedaan antara realisasi belanja dan anggaran belanja pada pemerintah daerah di Pulau Jawa selama kurun waktu 2013 s.d. 2016. Di tahun 2013, terdapat selisih anggaran sebesar Rp18,61 triliun dan di tahun 2016 terdapat selisih anggaran sebesar Rp16,287 triliun.

Adanya perbedaan atau selisih antara realisasi belanja dan anggaran belanja pada 
instansi pemerintah daerah tersebut menjadi salah satu indikasi bahwa telah terjadi kesenjangan (slack) anggaran dalam anggaran belanja daerah. Hal tersebut diungkapkan oleh Bitner (2005) yang menyebutkan bahwa pertumbuhan anggaran secara positif dan signifikan memengaruhi kesenjangan anggaran (budgetary slack).

Siegel dan Marconi dalam Jaya (2013) mendefinisikan kesenjangan (slack) anggaran sebagai selisih antara sumber daya yang sesungguhnya dibutuhkan untuk menyelesaikan pekerjaan secara efektif dengan sejumlah sumber daya yang ditambahkan untuk menyelesaikan pekerjaan tersebut. Kesenjangan tersebut dilakukan oleh manajer dengan cara mengestimasi bahwa pendapatan yang akan diperoleh lebih rendah dan/atau pengeluaran yang akan dikeluarkan lebih tinggi untuk suatu hal atau pekerjaan tertentu dalam periode tersebut. Hal ini bertujuan agar rencana yang telah ditetapkan dapat dicapai dengan mudah untuk memberikan kelonggaran kepada para manajer.

Kesenjangan anggaran ini tentu menimbulkan dampak yang tidak baik dalam pengelolaan keuangan suatu organisasi. Hal ini diungkapkan oleh Merchant (2014) bahwa terjadinya budgetary slack berdampak tidak baik karena dapat mengaburkan kinerja yang sesungguhnya sehingga mengubah keputusan berdasarkan informasi yang tidak akurat. Selain itu, budgetary slack juga dapat menimbulkan adanya sumber daya yang menganggur dan tidak terpakai.

Beberapa penelitian telah dilakukan terhadap faktor-faktor yang dapat menimbulkan kecenderungan melakukan kesenjangan anggaran. Faktor yang pertama adalah pertumbuhan anggaran. Bradshaw (2007) mengutip pernyataan Schiff dan Lewin bahwa manajer menciptakan kesenjangan anggaran dalam rangka membuat ruang untuk mengantisipasi biaya yang tidak pasti dan tidak terduga di tahun yang akan datang. Pertumbuhan anggaran didefinisikan sebagai besaran anggaran organisasi yang terus meningkat setiap tahunnya. Hasil penelitian Bradshaw (2007) menunjukkan bahwa secara parsial pertumbuhan anggaran berpengaruh negatif dan tidak signifikan terhadap budgetary slack. Sementara itu, Bitner (2005) menyebutkan bahwa pertumbuhan anggaran secara positif dan signifikan memengaruhi budgetary slack.

Faktor kedua yang dapat memengaruhi fenomena budgetary slack adalah partisipasi anggaran. Menurut Jaya (2013), partisipasi didefinisikan sebagai keikutsertaan manajer dalam penyusunan anggaran. Partisipasi anggaran juga diartikan sebagai keterlibatan pelaksana anggaran pada proses penyusunan suatu anggaran sehingga partisipasi anggaran diukur dengan menggunakan besaran anggaran belanja pegawai tiap-tiap daerah.

Faktor ketiga, kesenjangan anggaran juga dapat dipengaruhi karena adanya informasi asimetris. Merchant dan Van der Stede dalam Wiratama (2016) menyebutkan bahwa informasi asimetris adalah suatu keadaan ketika atasan memiliki pengetahuan yang kurang lengkap mengenai apa yang dapat dicapai oleh bawahan pada area tertentu. Hal ini dapat diartikan bahwa semakin besar anggaran pada level divisi atau pada detailed budget, maka semakin besar pula informasi asimetris yang dapat menyebabkan terjadinya kesenjangan anggaran.

Wiratama (2016) menyebutkan bahwa pertumbuhan anggaran, partisipasi anggaran, dan informasi asimetris berpengaruh signifikan terhadap budgetary slack dalam anggaran Pemerintah Pusat dalam Anggaran Pendapatan dan Belanja Negara. Ketiga faktor yang diteliti tersebut mewakili 28,5\% dari faktor-faktor yang menyebabkan fenomena budgetary slack yang terjadi pada anggaran kementerian/lembaga.

Dari uraian di atas, maka rumusan masalah penelitian ini sebagai berikut: (1) Apakah pertumbuhan anggaran berpengaruh terhadap kesenjangan anggaran belanja daerah? (2) Apakah partisipasi anggaran berpengaruh terhadap kesenjangan anggaran belanja daerah? (3) Apakah informasi asimetris berpengaruh terhadap kesenjangan anggaran belanja daerah? (4) Apakah pertumbuhan anggaran, partisipasi anggaran, dan informasi asimetris secara bersama-sama berpengaruh terhadap kesenjangan anggaran belanja daerah?

Penelitian ini bertujuan untuk menguji pengaruh 3 (tiga) variabel bebas pertumbuhan anggaran, partisipasi anggaran, dan informasi asimetris terhadap variabel tetap kesenjangan anggaran dalam anggaran belanja daerah, dalam hal ini adalah daerah provinsi, baik secara parsial maupun simultan. Adapun manfaat penelitian ini diharapkan dapat memberikan bahan evaluasi kepada pemerintah pusat maupun pemerintah daerah provinsi dalam penyempurnaan prosedur penyusunan anggaran daerah guna menghindari terjadinya potensi kesenjangan anggaran.

Riadi (2016) menjelaskan bahwa hipotesis nul $\left(\mathrm{H}_{0}\right)$, sering juga disebut hipotesis statistik, adalah hipotesis yang menyatakan tidak adanya perbedaan antara dua variabel atau tidak adanya pengaruh variabel $\mathrm{X}$ terhadap variabel $\mathrm{Y}$. Sebaliknya, hipotesis kerja $\left(\mathrm{H}_{1}\right)$ adalah hipotesis yang biasanya diuji untuk diterima dan dirumuskan oleh peneliti. Hipotesis kerja menyatakan adanya hubungan antara variabel $\mathrm{X}$ dan variabel Y. Oleh karena itu, hipotesis kerja yang dirumuskan dalam penelitian ini adalah: 
1) $\mathrm{H}_{11}$ : Pertumbuhan anggaran secara parsial berpengaruh terhadap kesenjangan anggaran belanja daerah.

2) $\mathrm{H}_{12}$ : Partisipasi anggaran secara parsial berpengaruh terhadap kesenjangan anggaran belanja daerah.

3) H13: Informasi asimetris secara parsial berpengaruh terhadap kesenjangan anggaran belanja daerah.

4) $\mathrm{H}_{14}:$ Pertumbuhan anggaran, partisipasi anggaran, dan informasi asimetris secara bersama-sama berpengaruh terhadap kesenjangan anggaran belanja daerah.

\section{KERANGKA TEORI DAN PENGEMBANGAN HIPOTESIS}

Berikut ini adalah kerangka teori yang digunakan dalam pengembangan hipotesis penelitian.

\subsection{Anggaran Belanja Daerah}

Anggaran belanja daerah merupakan salah satu komponen yang ada pada APBD selain komponen pendapatan dan komponen pembiayaan. Menurut Budidarma (2011), belanja daerah meliputi seluruh pengeluaran dari Rekening Kas Umum Daerah yang mengurangi ekuitas dana lancar, yang merupakan kewajiban daerah dalam satu tahun anggaran yang tidak akan diperoleh kembali pembayarannya kembali oleh pemerintah daerah.

Proses perencanaan dan penyusunan APBD mengacu pada Peraturan Pemerintah Nomor 58 Tahun 2005 tentang Pengelolaan Keuangan Daerah. Proses ini terdiri dari 5 (lima) tahap, yaitu penyusunan rencana kerja pemerintah daerah, penyusunan rancangan kebijakan umum APBD serta prioritas dan plafon anggaran sementara, penyusunan rencana kerja dan anggaran Satuan Kerja Pemerintah Daerah (SKPD), penyusunan rancangan Perda APBD, dan penetapan APBD. Penjelasan dari lima tahap proses tersebut adalah sebagai berikut.

\subsubsection{Penyusunan rencana kerja pemerintah daerah}

Penyusunan APBD didasarkan pada perencanaan yang sudah ditetapkan terlebih dahulu, mengenai program dan kegiatan yang akan dilaksanakan. Bila dilihat dari perspektif waktunya, perencanaan di tingkat pemerintah daerah dibagi menjadi tiga kategori, yaitu Rencana Jangka Panjang Daerah (RPJPD) untuk periode 20 tahun, Rencana Jangka Menengah Daerah (RPJMD) untuk periode 5 tahun, dan Rencana Kerja Pemerintah Daerah (RKPD) merupakan perencanaan tahunan daerah.
2.1.2 Penyusunan rancangan kebijakan umum APBD

Pada tahap ini akan dibahas tentang prioritas dan plafon anggaran sementara pada tiap-tiap daerah.

\subsubsection{Penyusunan rencana kerja dan anggaran SKPD}

Pengaturan pada aspek perencanaan diarahkan agar seluruh proses penyusunan APBD semaksimal mungkin dapat menunjukkan latar belakang pengambilan keputusan dalam penetapan arah kebijakan umum, skala prioritas, dan penetapan alokasi, serta distribusi sumber daya dengan melibatkan partisipasi masyarakat. Penyusunan anggaran dilakukan dengan tiga pendekatan, yaitu pendekatan kerangka pengeluaran jangka menengah (KPJM), pendekatan anggaran terpadu, dan pendekatan anggaran kinerja.

\subsubsection{Penyusunan rancangan Perda APBD}

Rencana Kerja Anggaran-SKPD yang telah disusun, dibahas, dan disepakati bersama antara Kepala SKPD dan Tim Anggaran Pemerintah Daerah (TAPD) digunakan sebagai dasar untuk penyiapan rancangan Perda APBD. Rancangan Perda ini disusun oleh pejabat pengelola keuangan daerah yang untuk selanjutnya disampaikan kepada kepala daerah.

\subsubsection{Penetapan APBD}

Menurut ketentuan dari Pasal 104 Peraturan Menteri Dalam Negeri Nomor 13 Tahun 2006, rancangan Perda beserta lampiran-lampirannya yang telah disusun dan disosialisasikan kepada masyarakat untuk selanjutnya disampaikan oleh kepala daerah kepada Dewan Perwakilan Rakyat Daerah (DPRD) paling lambat pada minggu pertama bulan Oktober tahun anggaran sebelumnya dari tahun anggaran yang direncanakan untuk mendapatkan persetujuan bersama. Pengambilan keputusan bersama ini harus sudah terlaksana paling lama 1 (satu) bulan sebelum tahun anggaran yang bersangkutan dimulai.

\subsection{Kesenjangan Anggaran}

Kesenjangan (slack) anggaran adalah selisih antara sumber daya yang sesungguhnya dibutuhkan untuk menyelesaikan pekerjaan secara efektif dengan sejumlah sumber daya yang ditambahkan untuk menyelesaikan pekerjaan tersebut (Siegel dan Marconi, dalam Jaya (2013)). Kesenjangan tersebut dilakukan oleh manajer dengan cara mengestimasi bahwa pendapatan yang akan diperoleh lebih rendah dan/atau mengestimasi bahwa pengeluaran yang akan dikeluarkan lebih tinggi untuk suatu hal atau pekerjaan tertentu dalam periode tersebut. Hal ini 
bertujuan agar rencana yang telah ditetapkan dapat dicapai dengan mudah untuk memberikan kelonggaran kepada para manajer.

Kesenjangan anggaran ini menimbulkan dampak negatif dalam pengelolaan keuangan suatu entitas atau organisasi. Menurut Merchant (2014), terjadinya budgetary slack berdampak tidak baik karena dapat mengaburkan kinerja yang sesungguhnya sehingga dapat mengubah keputusan berdasarkan informasi yang tidak akurat. Selain itu, budgetary slack juga dapat menimbulkan adanya sumber daya yang menganggur dan tidak terpakai.

\subsection{Faktor yang Memengaruhi Kesenjangan Anggaran}

Fenomena kesenjangan anggaran yang terjadi disebabkan oleh berbagai faktor. Sejumlah penelitian telah dilakukan terkait dengan analisis faktor-faktor yang dapat menimbulkan kecenderungan melakukan kesenjangan anggaran. Beberapa faktor yang memengaruhi kesenjangan anggaran adalah:

\subsubsection{Pertumbuhan anggaran}

Bradshaw (2007) mengutip pernyataan Schiff dan Lewin bahwa manajer menciptakan kesenjangan anggaran untuk membuat ruang untuk mengantisipasi biaya yang tidak pasti dan tidak terduga di tahun yang akan datang. Hasil penelitian Bradshaw (2007) menunjukkan bahwa secara parsial pertumbuhan anggaran berpengaruh negatif dan tidak signifikan terhadap budgetary slack. Sementara itu, Bitner (2005) menyebutkan bahwa pertumbuhan anggaran secara positif dan signifikan memengaruhi budgetary slack. Pertumbuhan anggaran didefinisikan oleh Bradshaw dalam Wiratama (2016) dengan mengukur indikator selisih dari pagu anggaran belanja tahun ini dibandingkan dengan tahun sebelumnya dengan satuan persentase.

\subsubsection{Partisipasi anggaran}

Menurut Jaya (2013), partisipasi didefinisikan sebagai keikutsertaan manajer dalam penyusunan anggaran. Semakin banyak personel yang berpartisipasi dalam penyusunan anggaran, maka semakin tinggi pula kemungkinan terjadinya slack. Partisipasi anggaran juga diartikan sebagai keterlibatan pelaksana anggaran pada proses penyusunan suatu anggaran sehingga partisipasi anggaran diukur dengan menggunakan besaran anggaran belanja pegawai pada tiap-tiap daerah. Hal tersebut berdasarkan uji korelasi yang dilakukan oleh Wiratama (2016) yang menyebutkan bahwa jumlah pegawai dan anggaran belanja pegawai memiliki tingkat hubungan yang yang sangat kuat dengan nilai pearson correlation sebesar 0,839.
Di sisi lain, Onsi (1973) menyatakan bahwa partisipasi anggaran justru mengurangi kesenjangan anggaran. Hal ini ditandai dengan adanya komunikasi positif yang dilakukan para manajer sehingga para bawahan tidak terdorong untuk menciptakan senjangan anggaran. Hartanti dalam Rukmana (2013) menyebutkan bahwa partisipasi dapat memengaruhi tingkat turunnya suatu senjangan anggaran.

\subsubsection{Informasi asimetris}

Merchant dan Van der Stede dalam Wiratama (2016) menyebutkan bahwa informasi asimetris atau asimetri informasi adalah suatu keadaan ketika atasan memiliki pengetahuan yang kurang lengkap mengenai apa yang dapat dicapai oleh bawahan pada area tertentu. Young (1985) menyatakan bahwa apabila bawahan semakin banyak memiliki informasi yang tidak diketahui atasan, maka bawahan tersebut akan semakin tidak jujur tentang tingkat produktivitas yang dapat dicapainya atau potensi terjadinya slack akan semakin tinggi.

Selanjutnya, Onsi (1973) menyebutkan bahwa informasi anggaran yang diterima manajemen puncak sulit menangkap terjadinya budgetary slack pada level operasional divisi atau pada detailed budget. Hal ini dapat diartikan bahwa semakin besar anggaran pada level divisi atau pada detailed budget, maka semakin besar pula informasi asimetris yang dapat menyebabkan terjadinya kesenjangan anggaran.

Wiratama (2016) menyebutkan bahwa variabel informasi asimetris dapat menggunakan data primer maupun data sekunder, namun dalam penelitian ini hanya menggunakan data sekunder sesuai dengan penelitian Bradshaw (2007) yang menggunakan ukuran ministry size dengan proksi besaran anggaran kementerian atau entitas dalam mengukur informasi asimetris. Sehubungan dengan hal tersebut, Bradshaw (2007, 23) menyatakan bahwa:

In larger entities it is less likely that budgetary slack will be detected, therefore more likely for slack to exist (Onsi, 1973). Therefore as the size of the company increases so will the potential for budgetary slack to exist. ... Size in this study will use the proxy of revenue, given that when revenue increases the size of the entity is also likely to increase. Therefore the higher the revenue the greater the chance that budgetary slack exists.

Sejalan dengan penelitian Bradshaw dalam Wiratama (2016), variabel informasi asimetris diukur dengan ukuran besaran anggaran belanja yang dialokasikan pada objek penelitian, yaitu pemerintah daerah. 


\subsubsection{Faktor lainnya}

Faktor lainnya yang juga dapat memengaruhi keterjadian fenomena kesenjangan anggaran adalah kestabilan organisasi. Onsi (1973) menyatakan bahwa fenomena budgetary slack dipengaruhi oleh kestabilan aktivitas organisasi, yaitu berupa pertumbuhan organisasi dan jumlah profit tahunan. Perusahaan dengan tingkat aktivitas organisasi yang tidak stabil memiliki tingkat keterjadian budgetary slack lebih tinggi dibandingkan dengan organisasi dengan tingkat aktivitas yang lebih stabil.

Selain itu, kesenjangan anggaran juga dapat disebabkan oleh budget emphasis. Jaya (2013) mendefinisikan budget emphasis sebagai suatu alat evaluatif manajer bawahan yang menekankan pada ukuran performansi akuntansi. Hirst dan Manzoni dalam Jaya (2013) menyatakan bahwa budget emphasis sangat menekankan pada aspek ukuran kinerja akuntansi. Tingginya budget emphasis menunjukkan tingginya perhatian manajer atas ukuran kinerja anggaran yang berdampak pada reward berupa gaji dan bonus. Hal ini yang kemudian mendorong para manajer untuk melakukan kesenjangan anggaran agar target kinerja dapat tercapai dengan mudah.

\section{METODOLOGI PENELITIAN}

\subsection{Jenis dan Sumber Data}

Jenis data yang digunakan dalam penelitian ini merupakan data kuantitatif. Data ini merupakan data sekunder, yaitu data yang telah diolah oleh pihak tertentu dan dipublikasikan secara luas sehingga data tersebut dapat langsung digunakan. Data penelitian diperoleh dari Anggaran Pendapatan dan Belanja Daerah (APBD), Laporan Keuangan Pemerintah Daerah (LKPD), dan data pendukung lainnya. Selain itu, terdapat data yang bersumber dari Undang-Undang, Peraturan Pemerintah, Peraturan Menteri, dan dokumen legal lainnya yang menjadi tambahan dalam kebutuhan analisis dalam penelitian ini.

\subsection{Objek Penelitian}

Objek penelitian adalah besaran anggaran belanja daerah dan realisasi belanja daerah provinsi. Ruang lingkup periode penelitian, yaitu rentang tahun 2008 s.d. 2016, adalah periode anggaran belanja daerah dan realisasi belanja daerah setelah ditetapkannya UU Nomor 32 Tahun 2004 tentang Pemerintahan Daerah. Berdasarkan kriteria tersebut, sampel penelitian adalah sebagaimana terdapat dalam Tabel 1.

Berdasarkan data yang diperoleh dari Direktorat Jenderal Perimbangan Keuangan, terdapat beberapa pemerintah provinsi yang tidak memiliki data anggaran belanja dan realisasi anggaran belanja yang merupakan objek penelitian ini. Tabel 1, yang merupakan ringkasan dari lampiran yang berisi ketersediaan data, menunjukkan bahwa pada tahun 2005 terdapat ketersediaan data sebanyak 29 (dua puluh sembilan) pemerintah provinsi. Sementara itu, pada tahun 2006 memiliki jumlah ketersediaan data sebanyak 28 (dua puluh delapan) pemerintah provinsi. Pada tahun 2007 hingga 2013 memiliki jumlah ketersediaan data sebanyak 33 (tiga puluh tiga) pemerintah provinsi dan pada tahun 2014 hingga 2016 memiliki jumlah ketersediaan data sebanyak 34 (tiga puluh empat) pemerintah provinsi. Penambahan jumlah provinsi tersebut disebabkan oleh ditetapkannya provinsi-provinsi baru di Indonesia.

Tabel 1: Sampel Penelitian

\begin{tabular}{|c|c|c|c|c|c|c|}
\hline & \multicolumn{6}{|c|}{ Tahun } \\
\hline & 2005 & 2006 & 2007 & 2008 & 2009 & 2010 \\
\hline \multirow[t]{3}{*}{$\begin{array}{l}\text { Jumlah } \\
\text { Ketersediaan } \\
\text { Data Pemerintah } \\
\text { Provinsi }\end{array}$} & 29 & 28 & 33 & 33 & 33 & 33 \\
\hline & \multicolumn{6}{|c|}{ Tahun } \\
\hline & 2011 & 2012 & 2013 & 2014 & 2015 & 2016 \\
\hline $\begin{array}{l}\text { Jumlah } \\
\text { Ketersediaan } \\
\text { Data Pemerintah } \\
\text { Provinsi }\end{array}$ & 33 & 33 & 33 & 34 & 34 & 34 \\
\hline $\begin{array}{l}\text { Sumber: } \\
\text { Perimbanga }\end{array}$ & lah & $\begin{array}{l}d a \\
a n\end{array}$ & & $k t o$ & & nder \\
\hline
\end{tabular}

Untuk memastikan bahwa data yang tersedia dapat memenuhi dan mewakili keseluruhan populasi, maka dilakukan perhitungan ketercukupan data (keterwakilan sampel penelitian) dengan formula Slovin. Adapun jumlah ketercukupan data berdasarkan formula Slovin ditunjukkan dalam rumus berikut ini.

Keterangan:

$$
n=\frac{N}{1+N e^{2}}
$$

$$
\begin{array}{ll}
\mathrm{n} & =\text { jumlah ketercukupan data } \\
\mathrm{N} & =\text { jumlah populasi } \\
e & =\text { tingkat kesalahan }
\end{array}
$$

Dengan jumlah populasi (N) sebesar 34 pemerintah provinsi dan dengan galat sebesar $5 \%$, maka jumlah kecukupan data sampel (n) adalah sebagai berikut.

$$
\begin{gathered}
n=\frac{N}{1+N e^{2}} \\
n=\frac{34}{1+\left(34 \times 0,05^{2}\right)} \\
n=\frac{34}{1+0,085} \\
n=31,33
\end{gathered}
$$


Berdasarkan perhitungan dengan formula Slovin, setidaknya jumlah data yang harus didukung untuk mewakili populasi adalah sebanyak 31,33 atau 32 pemerintah provinsi. Data anggaran belanja dan realisasi anggaran belanja yang tersedia sebanyak 33 pemerintah provinsi, diperoleh secara lengkap dalam periode waktu tahun 2007 hingga tahun 2016 sehingga jumlah sampel tersebut telah memenuhi syarat keterwakilan populasi.

Selanjutnya, karena variabel pertama dalam penelitian, yaitu pertumbuhan anggaran, memerlukan data tahun sebelumnya untuk dijadikan pembanding untuk diolah lebih lanjut, maka tahun 2007 dijadikan sebagai tahun dasar atau tahun ke-0, kemudian tahun 2008 dijadikan sebagai tahun ke-1, dan seterusnya. Dengan kata lain, periode waktu penelitian adalah anggaran belanja dan realisasi belanja pemerintah provinsi selama sembilan tahun, yaitu dari periode tahun 2008 hingga tahun 2016.

\subsection{Populasi dan Sampel Penelitian}

Menurut Sarwono (2012), populasi merupakan kesatuan yang mempunyai karakteristik yang sama dimana sampel akan kita tarik. Sebagai contoh, populasi adalah seluruh pegawai dalam suatu perusahaan yang akan diteliti. Sementara itu, sampel adalah sebagian kecil dari populasi yang digunakan sebagai objek yang akan diteliti.

Populasi yang ada dalam penelitian ini adalah seluruh pemerintah daerah provinsi yang ada di Indonesia. Sampel yang dipilih merupakan entitas pemerintah provinsi yang ada di Indonesia, yang merupakan entitas pemerintah daerah paling atas atau paling dekat keterkaitannya dengan entitas pemerintah pusat.

Pemilihan sampel dilakukan dengan cara purposive sampling, yaitu cara penarikan sampel dari suatu populasi didasarkan pada informasi yang tersedia sehingga perwakilannya terhadap populasi dapat dipertanggungjawabkan. Salah satu hal yang menjadi pertimbangan dalam pemilihan sampel adalah pemerintah provinsi yang memiliki data lengkap atas anggaran belanja daerah dan realisasi belanja daerah dalam periode tahun 2008-2016.

\subsection{Teknik Pengumpulan Data Penelitian}

Untuk memperoleh data yang diperlukan dalam rangka penelitian, peneliti mengumpulkan data melalui pencarian dalam APBD dan LKPD. Selain itu, peneliti juga menggunakan metode penelitian kepustakaan dari literatur yang sesuai dengan penelitian. Data diperoleh dari salah satu unit Eselon I di lingkungan Kementerian Keuangan Republik Indonesia, yaitu Direktorat Jenderal Perimbangan Keuangan, beserta kementerian/ lembaga lainnya di luar Kementerian Keuangan Republik Indonesia.

\subsection{Analisis Data}

Analisis data dilakukan untuk menguji pengaruh antara suatu variabel dengan variabel lain dan dinilai tingkat keterkaitannya. Dalam penelitian ini pertumbuhan anggaran, partisipasi anggaran, dan informasi asimetris merupakan variabel bebas, sedangkan kesenjangan anggaran belanja daerah merupakan variabel tetap.

Metode statistik yang digunakan adalah metode statistik model analisis regresi berganda. Sebelum pengujian terhadap hipotesis, terlebih dahulu dilakukan uji regresi klasik. Untuk mengolah data hasil penelitian, peneliti menggunakan aplikasi Microsoft Excel dan Statistical Package for Social Science (SPSS).

\subsection{Deskripsi Statistik Deskriptif}

Statistik deskriptif, sebagaimana yang disebutkan oleh Wiratama (2016), merupakan metode yang berkaitan dengan pengumpulan, penataan, dan penyajian data sehingga dapat memberikan gambaran mengenai suatu data agar lebih informatif dan lebih sederhana untuk dipahami. Statistik deskriptif dapat membantu untuk meringkas data mentah agar memperoleh pola sebaran data. Dalam penjelasan statistik deskriptif ini, peneliti menggunakan beberapa karakteristik yang tersedia dalam aplikasi pengolahan data. Karakteristik tersebut adalah rata-rata (mean), simpangan baku (standard deviation), serta nilai maksimum (maximum value) dan nilai minimum (minimum value).

\subsection{Uji Outlier}

Menurut Latan dalam Wiratama (2016), regresi linier mensyaratkan asumsi-asumsi yang wajib dipenuhi sebelum estimasi model dilakukan, salah satunya adalah dengan memastikan bahwa data harus bebas dari outlier. Latan dalam Wiratama (2016) mendefinisikan outlier sebagai nilai yang unik yang membedakannya dengan observasi lain di dalam set data. Salah satu cara atau metode untuk mendeteksi adanya data outlier adalah dengan menguji nilai Z-score.

\subsection{Uji Regresi Klasik}

Uji regresi klasik dilaksanakan untuk mendeteksi adanya normalitas, multikolinearitas, heteroskedastisitas, dan autokorelasi. Keempat hal tersebut merupakan faktor-faktor yang dapat menyebabkan ketidakakuratan dalam pengambilan kesimpulan yang dibuat dalam suatu penelitian yang dilakukan.

\subsection{Uji Hipotesis}

Setelah seluruh uji regresi klasik dilaksanakan dan diperoleh hasilnya yang sesuai, 
dilakukan pengujian atas hipotesis yang ada pada penelitian. Hipotesis diuji melalui uji simultan $(F-$ test) dan uji signifikansi parsial (t-test).

Widarjono (2010) menyatakan bahwa uji $\mathrm{F}$ digunakan untuk mengevaluasi pengaruh semua variabel independen terhadap variabel dependen. Uji $F$ ini bisa dijelaskan dengan menggunakan analisis varians. Sementara itu, Widarjono (2010) menyatakan bahwa uji $t$ digunakan untuk membuktikan apakah variabel independen secara individu memengaruhi variabel dependen.

Menurut Nazir (2005) dalam Riadi (2016, 85-86), salah satu jenis hipotesis adalah hipotesis kerja dan hipotesis nul. Hipotesis kerja $\left(\mathrm{H}_{1}\right)$ biasanya diuji untuk diterima dan dirumuskan oleh peneliti ilmu sosial. Hipotesis ini menyatakan adanya hubungan antara variabel $\mathrm{X}$ dan $\mathrm{Y}$, atau adanya perbedaan antara dua kelompok. Sebaliknya, hipotesis nul $\left(\mathrm{H}_{0}\right)$ biasanya dipakai dalam penelitian statistik, yang diuji dengan perhitungan statistik. Hipotesis nul menyatakan tidak adanya perbedaan antara dua variabel, atau tidak adanya pengaruh variabel $X$ terhadap variabel Y. Dengan kata lain, selisih antara variabel pertama dengan kedua adalah nol atau nihil.

\section{HASIL PENELITIAN}

\subsection{Deskripsi Data Penelitian}

Data yang digunakan dalam penelitian ini merupakan data sekunder yang diperoleh dari Direktorat Jenderal Perimbangan Keuangan, Kementerian Keuangan Republik Indonesia, yang dipublikasikan secara luas kepada masyarakat melalui laman www.djpk.depkeu.go.id. Penulis menggunakan data anggaran belanja daerah dan realisasi anggaran belanja daerah pada pemerintah provinsi untuk kurun waktu 2008 hingga 2016.

Objek yang diteliti adalah besaran anggaran belanja daerah dan realisasinya pada seluruh pemerintah provinsi di Indonesia yang berjumlah 33 (tiga puluh tiga) provinsi dan selama sembilan tahun. Data yang digunakan untuk pengolahan penelitian adalah sebagaimana yang tersaji dalam Tabel 2 .

Besaran anggaran belanja daerah dalam APBD setiap tahunnya memiliki tren yang terus meningkat. Sebagaimana sejumlah penelitian yang telah dilakukan sebelumnya dan yang telah peneliti uraikan di bagian kerangka teori, peningkatan jumlah anggaran belanja daerah ini menunjukkan interpretasi terhadap variabel informasi asimetris. Jumlah anggaran belanja daerah dari 33 (tiga puluh tiga) pemerintah provinsi pada tahun 2008 adalah sebesar Rp96,233 triliun. Jumlah ini cenderung terus meningkat setiap tahunnya hingga sebesar Rp291,466 triliun pada tahun 2016.
Tabel 2: Data Penelitian

\begin{tabular}{|c|c|c|c|}
\hline No. & $\begin{array}{c}\text { Data } \\
\text { APBD }\end{array}$ & $\begin{array}{c}\text { Kesenjangan } \\
\text { Anggaran } \\
\text { (Rp) }\end{array}$ & $\begin{array}{l}\text { Pertumbuhan } \\
\text { Anggaran } \\
(\%)\end{array}$ \\
\hline 1. & 2008 & (1.181.967.499.599) & 38,97 \\
\hline 2. & 2009 & 1.511 .625 .748 .940 & 9,64 \\
\hline 3. & 2010 & 1.647.130.586.779 & 7,23 \\
\hline 4. & 2011 & $(4.316 .171 .027 .592)$ & 13,07 \\
\hline 5. & 2012 & (5.293.769.366.145) & 36,04 \\
\hline 6. & 2013 & 10.016.866.951.117 & 22,36 \\
\hline 7. & 2014 & 37.361 .209 .826 .903 & 20,22 \\
\hline 8. & 2015 & 28.273.365.801.978 & 7,51 \\
\hline 9. & 2016 & 30.065 .717 .310 .972 & 5,91 \\
\hline No. & $\begin{array}{c}\text { Data } \\
\text { APBD }\end{array}$ & $\begin{array}{l}\text { Partisipasi } \\
\text { Anggaran } \\
\text { (Rp) }\end{array}$ & $\begin{array}{l}\text { Informasi } \\
\text { Asimetris } \\
\text { (Rp) }\end{array}$ \\
\hline 1. & 2008 & 6.455 .185 .658 .295 & 96.233 .757 .036 .474 \\
\hline 2. & 2009 & 6.431 .342 .704 .567 & 105.508 .128 .869 .533 \\
\hline 3. & 2010 & 11.354 .824 .704 .683 & 113.133 .300 .391 .639 \\
\hline 4. & 2011 & 5.718 .579 .220 .065 & 127.918.631.381.718 \\
\hline 5. & 2012 & 6.491 .971 .998 .817 & 174.016 .403 .859 .455 \\
\hline 6. & 2013 & 7.922 .300 .500 .968 & 212.918 .920 .716 .284 \\
\hline 7. & 2014 & 8.006.567.241.375 & 255.976 .829 .633 .970 \\
\hline 8. & 2015 & 7.096 .319 .034 .065 & 275.197.355.579.505 \\
\hline 9. & 2016 & 7.004 .570 .563 .946 & 291.466.561.853.938 \\
\hline
\end{tabular}

Sumber: Diolah dari Direktorat Jenderal Perimbangan Keuangan

Peningkatan jumlah anggaran belanja daerah tersebut juga diikuti dengan peningkatan jumlah anggaran belanja pegawai. Sebagaimana penelitian yang telah dilakukan dan telah dijelaskan pada landasan teori, peningkatan jumlah anggaran belanja pegawai ini menunjukkan interpretasi terhadap variabel partisipasi anggaran. Sepanjang periode tahun 2008 hingga 2016, terjadi peningkatan dan penurunan anggaran belanja pegawai. Jumlah partisipasi anggaran pada tahun 2008 adalah sebesar Rp6,455 triliun, sedangkan tahun 2016 meningkat hingga mencapai Rp7,004 triliun.

Variabel pertumbuhan anggaran juga mengalami peningkatan dan penurunan dibandingkan anggaran tahun sebelumnya dalam periode tahun 2008 hingga 2016. Pada tahun 2008, pertumbuhan anggaran mencapai hingga 38,97\% dari jumlah anggaran belanja tahun sebelumnya. Angka ini juga merupakan angka pertumbuhan tertinggi dalam periode data penelitian. Dalam APBD tahun 2016, pertumbuhan anggaran mencapai 5,91\% dari anggaran belanja tahun sebelumnya.

Hal yang terjadi pada variabel pertumbuhan anggaran sebagai variabel bebas dalam penelitian, 
juga ditunjukkan pada variabel kesenjangan anggaran sebagai variabel tetap. Variabel kesenjangan anggaran juga mengalami peningkatan dan penurunan selama periode tahun 2008 hingga 2016. Pada tahun 2008, jumlah kesenjangan anggaran adalah sebesar $\operatorname{Rp}(1,181$ triliun), sedangkan pada tahun 2016, jumlah kesenjangan anggaran adalah sebesar Rp30,065 triliun.

\subsection{Deskripsi Statistik Deskriptif}

Statistik deskriptif, sebagaimana yang disebutkan oleh Wiratama (2016), merupakan metode yang berkaitan dengan pengumpulan, penataan, dan penyajian data sehingga dapat memberikan gambaran mengenai suatu data agar lebih informatif dan lebih sederhana untuk dipahami. Statistik deskriptif dapat membantu untuk meringkas data mentah agar memperoleh pola sebaran data.

Dalam penjelasan statistik deskriptif ini, penulis menggunakan beberapa karakteristik yang tersedia dalam aplikasi pengolahan data, yaitu aplikasi SPSS. Karakteristik tersebut antara lain rata-rata (mean), simpangan baku (standard deviation), serta nilai maksimum (maximum value) dan nilai minimum (minimum value). Adapun deskripsi dari statistik deskriptif tersebut adalah sebagai berikut.

\subsubsection{Variabel kesenjangan anggaran}

Berdasarkan hasil olah pada aplikasi SPSS, statistik deskriptif untuk variabel kesenjangan anggaran sebagai berikut: nilai minimum dari variabel kesenjangan anggaran adalah 0 dan nilai maksimumnya adalah 37,361 triliun. Dari sembilan tahun periode waktu, nilai rata-rata dari variabel kesenjangan anggaran adalah sebesar 12,097 triliun dan simpangan baku sebesar 15,359 triliun.

\subsubsection{Variabel pertumbuhan anggaran}

Berdasarkan hasil olah pada aplikasi SPSS, statistik deskriptif untuk variabel pertumbuhan anggaran sebagai berikut: nilai minimum dan maksimum dari variabel pertumbuhan anggaran adalah 5,91 dan 38,97. Dari sembilan tahun periode waktu, nilai rata-rata dari variabel pertumbuhan anggaran adalah sebesar 17,89 dan simpangan baku sebesar 12,53.

\subsubsection{Variabel partisipasi anggaran}

Berdasarkan hasil olah pada aplikasi SPSS, statistik deskriptif untuk variabel partisipasi anggaran sebagai berikut: nilai minimum dari variabel ini adalah 5,718 triliun dan nilai maksimumnya adalah 11,354 triliun. Dari sembilan tahun periode waktu, nilai rata-rata dari variabel partisipasi anggaran adalah sebesar 7,386 triliun dan simpangan baku sebesar 1,658 triliun.

\subsubsection{Variabel informasi asimetris}

Berdasarkan hasil olah pada aplikasi SPSS, statistik deskriptif untuk variabel informasi asimetris sebagai berikut: nilai minimum dari variabel informasi asimetris adalah 96,233 triliun dan nilai maksimumnya adalah 291,466 triliun. Dari sembilan tahun periode waktu, nilai rata-rata dari variabel informasi asimetris adalah sebesar 183,596 triliun dan simpangan baku sebesar 77,469 triliun.

\subsection{Uji Outlier}

Nilai Z-score yang dihasilkan untuk data yang digunakan dalam penelitian ini ditunjukkan dalam Tabel 3. Latan dalam Wiratama (2016) menyebutkan bahwa data outlier ditunjukkan dengan set data yang memiliki nilai Z-score sebesar $>2,5$ untuk jumlah sampel kecil atau kurang dari 80 set data. Sementara itu, untuk sampel besar atau lebih dari 80 set data, outlier ditunjukkan dengan nilai Z-score sebesar $>4$.

\section{Tabel 3: Nilai Z-Score Variabel Penelitian}

\begin{tabular}{|c|c|c|c|c|}
\hline \multirow{2}{*}{ No. } & \multicolumn{4}{|c|}{ Z-Score } \\
\cline { 2 - 5 } & $\begin{array}{c}\text { Kesenjangan } \\
\text { Anggaran }\end{array}$ & $\begin{array}{c}\text { Pertumbuhan } \\
\text { Anggaran }\end{array}$ & $\begin{array}{c}\text { Partisipasi } \\
\text { Anggaran }\end{array}$ & $\begin{array}{c}\text { Informasi } \\
\text { Asimetris }\end{array}$ \\
\hline 1. & $-0,78759$ & 1,68331 & $-0,56167$ & $-1,12771$ \\
\hline 2. & $-0,68918$ & $-0,65805$ & $-0,57605$ & $-1,-799$ \\
\hline 3. & $-0,68035$ & $-0,85043$ & 2,39218 & $-0,90956$ \\
\hline 4. & $-0,78759$ & $-0,38424$ & $-1,-575$ & $-0,71871$ \\
\hline 5. & $-0,78759$ & 1,44941 & $-0,53950$ & $-0,12366$ \\
\hline 6. & $-0,13545$ & 0,35736 & 0,32281 & 0,37850 \\
\hline 7. & 1,64479 & 0,18653 & 0,37361 & 0,93430 \\
\hline 8. & 1,05313 & $-0,82808$ & $-0,17515$ & 1,18241 \\
\hline 9. & 1,16982 & $-0,95581$ & $-0,23047$ & 1,39242 \\
\hline
\end{tabular}

Sumber: Hasil pengolahan dengan SPSS

Berdasarkan data dalam Tabel 3 diketahui bahwa dari keempat variabel, baik variabel bebas dan variabel tetap, yang digunakan dalam penelitian ini, tidak ada data yang memiliki nilai Zscore $>2,5$. Mengingat jumlah sampel yang digunakan dalam penelitian ini adalah kecil, yaitu sebanyak 33 set data, maka dalam set data ini tidak terdapat outlier.

\subsection{Uji Regresi Klasik}

\subsubsection{Uji normalitas}

Uji normalitas dapat dilakukan dengan melihat sebaran titik-titik yang ada pada gambar hasil pengujian yang dihasilkan melalui aplikasi pengolahan data. Dalam Gambar 2, yang merupakan hasil uji normalitas dalam penelitian ini, terlihat bahwa sebaran titik-titik dari hasil uji normalitas di atas relatif mendekati garis lurus diagonal yang melintang di antara dua sudut.

Gambar 2: Hasil Uji Normalitas 
Normal P-P Plot of Regression Standardized Residual

Dependent Variable: BSLACK

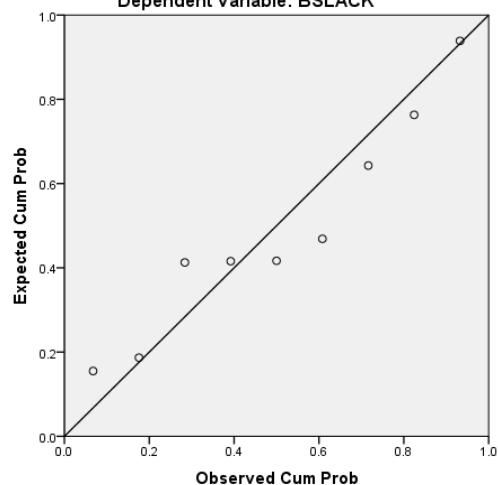

Observed Cum Prob

Sumber: Hasil pengolahan dengan SPSS

Hal tersebut menunjukkan bahwa data yang diuji dalam penelitian tersebut terdistribusi secara normal. Hal ini sejalan dengan asumsi klasik dari regresi linier dengan pendekatan OLS, yaitu data residual yang dibentuk model regresi linier terdistribusi secara normal, bukan variabel bebas ataupun variabel terikatnya.

Selain itu, uji normalitas juga dapat dilakukan dengan uji Kolmogorov-Smirnov Goodness of Fit dalam aplikasi SPSS (Sarwono, 2012). Uji normalitas tersebut digunakan untuk mengetahui apakah distribusi nilai dalam sampel sesuai dengan distribusi teoretis tertentu, misalnya normalitas data. Hasil dari uji tersebut tersaji dalam Tabel 4.

Tabel 4: Hasil Uji Normalitas

\begin{tabular}{|c|c|c|c|c|}
\hline & $\begin{array}{c}\text { Kesenjangan } \\
\text { Anggaran }\end{array}$ & $\begin{array}{c}\text { Pertumbuhan } \\
\text { Anggaran }\end{array}$ & $\begin{array}{c}\text { Partisipasi } \\
\text { Anggaran }\end{array}$ & $\begin{array}{c}\text { Informasi } \\
\text { Asimetris }\end{array}$ \\
\hline $\begin{array}{c}\text { Asymp. } \\
\text { Sig. } \\
(2- \\
\text { tailed })\end{array}$ & 0,363 & 0,843 & 0,661 & 0,830 \\
\hline
\end{tabular}

Sumber: Hasil pengolahan dengan SPSS

Hasil uji normalitas pada Tabel 4 menunjukkan bahwa nilai asymp. sig. (2-tailed) dari keempat variabel dalam penelitian seluruhnya memiliki nilai lebih dari 0,05. Dengan demikian, data yang digunakan dalam penelitian ini telah berdistribusi normal.

\subsubsection{Uji multikolinearitas}

Uji multikolineritas merupakan hubungan linier antara variabel independen di dalam regresi berganda (Widarjono, 2010). Berdasarkan syarat asumsi klasik regresi linier dengan OLS, model regresi linier yang baik adalah yang terbebas dari adanya multikolinearitas (Iqbal, 2015). Uji multikolinearitas dilakukan dengan melihat nilai VIF (\%) untuk tiap-tiap variabel bebas dalam penelitian. Nilai tersebut kemudian dibandingkan dengan nilai alpha, yaitu 5 persen. Hasil uji multikolinearitas dalam penelitian ini adalah sebagaimana terdapat dalam Tabel 5 berikut ini.

Tabel 5: Hasil Uji SPSS - Coefficients

\begin{tabular}{|c|l|c|c|c|c|} 
No. & \multicolumn{1}{|c|}{ Variabel } & $\mathrm{t}$ & Sig. & Tolerance & VIF \\
\hline 1. & $\begin{array}{l}\text { Pertumbuhan } \\
\text { Anggaran }\end{array}$ & $-0,369$ & 0,727 & 0,814 & 1,229 \\
\hline 2. & $\begin{array}{l}\text { Partisipasi } \\
\text { Anggaran }\end{array}$ & 0,359 & 0,734 & 0,891 & 1,122 \\
\hline 3. & $\begin{array}{l}\text { Informasi } \\
\text { Asimetris }\end{array}$ & 4,522 & 0,006 & 0,897 & 1,115 \\
\hline
\end{tabular}

Sumber: Hasil pengolahan dengan SPSS

Nilai VIF untuk ketiga variabel bebas menunjukkan nilai masing-masing sebesar 1,229, 1,122, dan 1,115 dengan nilai tolerance adalah sebesar di bawah 1. Karena nilai VIF pada hasil uji tersebut tidak lebih besar dari 5, maka dapat dikatakan bahwa tidak terjadi multikolinieritas pada ketiga variabel bebas dalam data tersebut.

\subsubsection{Uji heteroskedastisitas}

Heteroskedastisitas berarti varian variabel gangguan yang tidak konstan. Salah satu asumsi metode OLS adalah bahwa varian variabel gangguan sama atau homoskedastisitas (Widarjono, 2010).

Sementara itu, menurut Iqbal (2015), pengujian heteroskedastisitas dilakukan dengan membuat scatterplot (alur sebaran) antara residual dan nilai prediksi dari variabel terikat yang telah distandardisasi. Pengujian heteroskedastisitas mencerminkan varian variabel pada model regresi tidak sama atau tidak konstan. Sementara itu, jika varian variabel pada model regresi memiliki nilai yang sama, maka disebut dengan homoskedastisitas.

Hasil uji heteroskedastisitas tersaji pada Gambar 3. Dari Gambar 3 tersebut, terlihat bahwa sebaran titik-titik yang ada dalam kotak tidak membentuk suatu pola atau alur tertentu yang teratur sehingga dapat dikatakan tidak terjadi heteroskedastisitas. Dengan demikian, asumsi klasik tentang heteroskedastisitas dalam model ini terpenuhi atau dapat disimpulkan bahwa data dalam penelitian ini tidak terjadi heteroskedastisitas.

Gambar 3: Hasil Uji Heteroskedastisitas

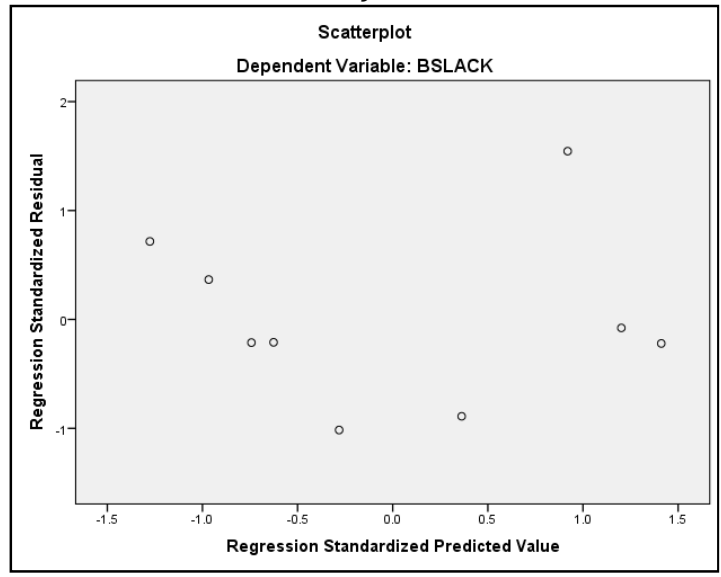

Sumber: Hasil pengolahan dengan SPSS 


\subsubsection{Uji autokorelasi}

Autokorelasi merupakan korelasi antara variabel gangguan satu observasi dengan variabel gangguan lainnya. Autokorelasi ini seringkali muncul pada penelitian dengan data time series. Salah satu asumsi metode OLS adalah tidak adanya korelasi antara variabel gangguan (Widarjono, 2010). Uji autokorelasi dilakukan dengan melihat nilai Durbin-Watson dari pengolahan pada aplikasi SPSS yang kemudian dibandingkan dengan nilai pada Tabel Durbin-Watson. Adapun hasil uji autokorelasi dapat dilihat pada Tabel 6.

Tabel 6: Hasil Uji SPSS - Model Summary

\begin{tabular}{|c|c|c|c|c|c|}
\hline Model & $R$ & $R$ Square & $\begin{array}{c}\text { Adjusted } R \\
\text { Square }\end{array}$ & $\begin{array}{l}\text { Std. Error of the } \\
\text { Estimate }\end{array}$ & $\begin{array}{l}\text { Durbin- } \\
\text { Watson }\end{array}$ \\
\hline 1 & $0,911^{a}$ & 0,829 & 0,727 & $8.032 .711 .480 .408,2$ & 1,939 \\
\hline
\end{tabular}

Hasil uji autokorelasi ditunjukkan pada kolom Durbin-Watson hasil analisis dalam Tabel 6 yaitu sebesar 1,939. Angka ini kemudian dibandingkan dengan kriteria penerimaan atau penolakan yang disimbolkan melalui nilai Durbin Lower (dL) dan Durbin Upper (dU). Tidak adanya autokorelasi ditandainya dengan nilai Durbin-Watson hasil pengolahan berada dalam lingkup dU dan 4-dU.

Untuk dapat membaca tabel Durbin-Watson, dilakukan dengan melihat jumlah variabel bebas (k) dalam model regresi dan jumlah sampel (n) dalam Tabel IV.10 dengan tingkat signifikansi sebesar $5 \%$ atau 0,05 .

Tabel 7: Durbin-Watson (5\%)

\begin{tabular}{|c|c|c|c|c|c|c|}
\hline \multirow{2}{*}{$\mathrm{n}$} & \multicolumn{2}{|c|}{$\mathrm{k}=2$} & \multicolumn{2}{c|}{$\mathrm{k}=3$} & \multicolumn{2}{c|}{$\mathrm{k}=4$} \\
\cline { 2 - 7 } & $\mathrm{dL}$ & $\mathrm{dU}$ & $\mathrm{dL}$ & $\mathrm{dU}$ & $\mathrm{dL}$ & $\mathrm{dU}$ \\
\hline 7 & 0,467 & 1,896 & - & - & - & - \\
\hline 8 & 0,559 & 1,777 & 0,367 & 2,287 & - & - \\
\hline 9 & 0,629 & 1,699 & $\mathbf{0 , 4 5 5}$ & $\mathbf{2 , 1 2 8}$ & 0,296 & 2,588 \\
\hline 10 & 0,697 & 1,641 & 0,525 & 2,016 & 0,377 & 2,414 \\
\hline$\ldots$ & $\ldots$ & $\ldots$ & $\ldots$ & $\ldots$ & $\ldots$ & $\ldots$ \\
\hline
\end{tabular}

Sumber: Diolah dari Ghozali (2016)

Dari hasil pengamatan pada Tabel 7 tersebut, untuk nilai $\mathrm{k}$ sebanyak 3 dan nilai $\mathrm{n}$ sebesar 9 menghasilkan nilai $\mathrm{dL}$ dan $\mathrm{dU}$ masing-masing sebesar 0,455 dan 2,128. Dari angka tersebut, maka kriteria autokorelasi dapat digambarkan dalam Gambar 4 berikut ini.

\begin{tabular}{|c|c|c|c|c|}
\hline \multicolumn{5}{|c|}{ Gambar 4: Hasil Uji Autokorelasi } \\
\hline \multicolumn{2}{|c|}{ dL } & 4-dU & \multicolumn{2}{|c|}{ 4-dL } \\
\hline $\begin{array}{l}\text { Autokorelasi } \\
\text { Positif }\end{array}$ & $\begin{array}{l}\text { Ragu- } \\
\text { ragu }\end{array}$ & $\begin{array}{l}\text { Tidak Ada } \\
\text { Autokorelasi }\end{array}$ & $\begin{array}{l}\text { Ragu- } \\
\text { ragu }\end{array}$ & $\begin{array}{l}\text { Autokorelasi } \\
\text { Negatif }\end{array}$ \\
\hline 0,4 & & 72 & & 45 \\
\hline
\end{tabular}

Nilai Durbin-Watson dalam penelitian ini menunjukkan nilai 1,939. Nilai tersebut jika dimasukkan ke dalam Tabel 8 berada dalam rentang dU dan 4-dU, yaitu dengan nilai tidak ada autokorelasi, berada di antara nilai 1,872 hingga 2,128. Oleh karena itu, dapat disimpulkan bahwa dalam model regresi linier tidak terjadi autokorelasi.

Selain itu, menurut Raharjo (2017), uji autokorelasi juga dapat dilakukan melalui Runs Test dalam aplikasi SPSS. Runs Test dapat dilakukan dengan melihat nilai asymp. sig. (2tailed). Jika nilai asymp. sig. (2-tailed) lebih kecil daripada 0,05 atau $5 \%$, maka terdapat gejala autokorelasi dalam data penelitian. Sementara itu, jika nilai asymp. sig. (2-tailed) lebih besar daripada 0,05 atau 5\%, maka tidak terdapat gejala autokorelasi. Hasil perhitungan Runs Test pada data penelitian adalah sebagai berikut.

\section{Tabel 8: Hasil Uji Runs Test}

\begin{tabular}{|l|r|}
\hline & \multicolumn{2}{|c|}{ Unstandardized Residual } \\
\hline Test Value & $-1689718801599,36550$ \\
\hline Cases $<$ Test Value & 4 \\
\hline Cases $>=$ Test Value & 5 \\
\hline Total Cases & 9 \\
\hline Number of Runs & 4 \\
\hline$Z$ & -683 \\
\hline Asymp. Sig. (2-tailed) &, 495 \\
\hline
\end{tabular}

Sumber: Hasil pengolahan dengan SPSS

Berdasarkan Tabel 8 tersebut, diketahui bahwa nilai asymp. sig. (2-tailed) adalah sebesar 0,495 . Nilai ini merupakan nilai yang lebih besar dibandingkan dengan 0,05 atau 5\% sehingga dapat dikatakan bahwa tidak terdapat gejala autokorelasi dalam data penelitian ini.

\subsection{Pengujian Hipotesis}

Setelah dilakukan uji regresi klasik sebagaimana yang telah dijabarkan sebelumnya dan ditunjukkan bahwa model sudah dapat digunakan untuk melakukan pengujian analisis regresi berganda, selanjutnya adalah pengujian atas hipotesis penelitian.

\subsubsection{Analisis koefisien determinasi}

Analisis koefisien determinasi menunjukkan variasi pengaruh variabel bebas yang diujikan terhadap variabel terikat yang ada. Koefisien determinasi ditentukan dengan nilai $R$ Square untuk 1 (satu) variabel bebas. Sementara itu, nilai Adjusted $R$ Square untuk menentukan koefisien determinasi dengan variabel bebas yang diujikan berjumlah 2 (dua) atau lebih. Nilai koefisien determinasi tersaji pada Tabel 6 .

Dalam hasil analisis yang dilakukan melalui aplikasi SPSS, nilai Adjusted R Square adalah 0,727 yang mencerminkan bahwa pengaruh ketiga variabel bebas, yaitu pertumbuhan anggaran, partisipasi anggaran, dan informasi asimetris, terhadap variabel terikat kesenjangan anggaran 
adalah sebesar 72,7\%. Sementara itu, 27,3\% (100\% dikurangi dengan $72,7 \%$ ) dipengaruhi oleh variabel lain yang tidak diteliti dalam penelitian ini.

\subsubsection{Uji simultan (F-Test)}

Hasil uji $\mathrm{F}$ diperoleh dari hasil pengolahan data dengan SPSS. Nilai prob. F-stat yang diperoleh adalah sebesar 8,084 dan nilai sig. sebesar 0,023 atau lebih kecil dari taraf nyata $(\alpha) 5 \%$ atau 0,05 .

Hal ini berarti bahwa model regresi linier yang diestimasi dalam penelitian ini dapat digunakan atau layak untuk menjelaskan pengaruh yang signifikan dari variabel bebas pertumbuhan anggaran, partisipasi anggaran, dan informasi asimetris terhadap variabel terikat kesenjangan anggaran.

\subsubsection{Hasil uji parsial (t-test)}

Hasil uji $t$ yang diperoleh dari hasil pengolahan dengan SPSS dapat dilihat pada Tabel 5. Nilai sig untuk variabel pertumbuhan anggaran adalah 0,727, variabel partisipasi anggaran adalah 0,734 , dan variabel informasi asimetris adalah 0,006 .

Apabila nilai sig kurang dari taraf nyata $(\alpha)$ 0,05 atau 5\%, maka variabel bebas tersebut berpengaruh signifikan terhadap variabel terikat. Sebaliknya, apabila nilai sig lebih besar dari taraf nyata $(\alpha) \quad 0,05$ atau $5 \%$, maka variabel bebas tersebut tidak berpengaruh signifikan terhadap variabel terikat.

\subsubsection{Analisis hipotesis}

Berdasarkan uraian sebelumnya, berikut ini adalah analisis atas hipotesis penelitian ini.

1) $H_{11}$ : Pertumbuhan anggaran secara parsial berpengaruh terhadap kesenjangan anggaran belanja daerah.

Nilai sig pertumbuhan anggaran secara parsial adalah 0,727. Karena nilai sig $>0,05$, maka penelitian ini tidak menolak Hipotesis $\mathrm{Nul}\left(\mathrm{H}_{0}\right)$. Oleh karena itu, dapat disimpulkan bahwa variabel pertumbuhan anggaran secara parsial tidak berpengaruh terhadap variabel kesenjangan anggaran belanja daerah, pada taraf nyata $5 \%$.

Kesimpulan ini sejalan dengan hasil penelitian Bradshaw (2007) yang menunjukkan bahwa secara parsial pertumbuhan anggaran berpengaruh negatif dan tidak signifikan terhadap budgetary slack. Sebaliknya, hal ini bertentangan dengan kesimpulan yang diungkapkan oleh Bitner (2005) yang menyebutkan bahwa pertumbuhan anggaran secara positif dan signifikan memengaruhi kesenjangan anggaran.

2) $\mathrm{H}_{12}$ : Partisipasi anggaran secara parsial berpengaruh terhadap kesenjangan anggaran belanja daerah.
Nilai sig partisipasi anggaran secara parsial adalah 0,734. Karena nilai sig>0,05, maka penelitian ini tidak menolak Hipotesis $\mathrm{Nul}\left(\mathrm{H}_{0}\right)$. Oleh karena itu, dapat disimpulkan bahwa variabel partisipasi anggaran secara parsial tidak berpengaruh terhadap variabel kesenjangan anggaran belanja daerah, pada taraf nyata $5 \%$.

Hal ini senada dengan Onsi (1973) yang menyatakan bahwa partisipasi anggaran justru mengurangi kesenjangan anggaran. Hal ini dapat ditandai dengan adanya komunikasi positif yang dilakukan para manajer sehingga para bawahan tidak terdorong untuk menciptakan kesenjangan anggaran.

Hartanti dalam Rukmana (2013) menyebutkan bahwa partisipasi dapat memengaruhi tingkat turunnya suatu senjangan anggaran.

3) $\mathrm{H}_{13}$ : Informasi asimetris secara parsial berpengaruh terhadap kesenjangan anggaran belanja daerah.

Nilai sig informasi asimetris secara parsial adalah 0,006. Karena nilai sig<0,05, maka penelitian ini menolak Hipotesis $\mathrm{Nul}\left(\mathrm{H}_{0}\right)$. Oleh karena itu, dapat disimpulkan bahwa variabel informasi asimetris secara parsial berpengaruh terhadap variabel kesenjangan anggaran belanja daerah, pada taraf nyata $5 \%$.

Hal ini sesuai dengan penelitian Onsi (1973) yang menyebutkan bahwa informasi anggaran yang diterima manajemen puncak sulit menangkap terjadinya budgetary slack pada level operasional divisi atau pada detailed budget. Hal ini dapat diartikan bahwa semakin besar anggaran pada level divisi atau pada detailed budget, maka semakin besar pula informasi asimetris yang dapat menyebabkan terjadinya kesenjangan anggaran.

4) $\mathrm{H}_{14}$ : Pertumbuhan anggaran, partisipasi anggaran, dan informasi asimetris secara bersama-sama berpengaruh terhadap kesenjangan anggaran belanja daerah.

Nilai prob. F stat atau sig adalah 0,023. Karena nilai sig<0,05, maka penelitian ini menolak Hipotesis $\mathrm{Nul}\left(\mathrm{H}_{0}\right)$. Oleh karena itu, dapat disimpulkan bahwa variabel pertumbuhan anggaran, partisipasi anggaran, dan informasi asimetris secara bersama-sama berpengaruh terhadap variabel kesenjangan anggaran belanja daerah, pada taraf nyata $5 \%$. Hal ini sesuai dengan hasil penelitian yang dilakukan oleh Wiratama (2016) yang menyebutkan bahwa pertumbuhan anggaran, partisipasi anggaran, dan informasi asimetris berpengaruh signifikan terhadap budgetary slack.

Selain itu, berdasarkan hasil uji koefisien determinasi diketahui bahwa kombinasi ketiga 
variabel independen, yaitu variabel pertumbuhan anggaran, partisipasi anggaran, dan informasi asimetris mampu menjelaskan sebesar $72,7 \%$ dari fenomena kesenjangan anggaran belanja daerah yang terjadi. Sisanya, sebesar 27,3\%, kesenjangan anggaran belanja daerah dipengaruhi oleh variabel lain yang tidak diteliti dalam penelitian ini. Adapun ringkasan dari hasil uji hipotesis dalam penelitian ini disajikan dalam Tabel 9 berikut ini.

Tabel 9: Ringkasan Hasil Uji Hipotesis

\begin{tabular}{|c|l|c|}
\hline No. & \multicolumn{1}{|c|}{ Variabel } & Hipotesis Nul \\
\hline 1. & Pertumbuhan Anggaran & Tidak menolak \\
\hline 2. & Partisipasi Anggaran & Tidak menolak \\
\hline 3. & Informasi Asimetris & Menolak \\
\hline 4. & $\begin{array}{l}\text { Pertumbuhan Anggaran, } \\
\text { Partisipasi Anggaran, dan } \\
\text { Informasi Asimetris }\end{array}$ & Menolak \\
\hline
\end{tabular}

\section{KESIMPULAN DAN SARAN}

\subsection{Kesimpulan}

Pada pelaksanaan anggaran belanja daerah provinsi terdapat fenomena kesenjangan anggaran atau budgetary slack. Fenomena ini dipengaruhi secara bersama-sama oleh faktor pertumbuhan anggaran, partisipasi anggaran, dan informasi asimetris. Besarnya pengaruh ketiga faktor tersebut secara bersama-sama terhadap kesenjangan anggaran adalah sebesar 72,7\%. Besarnya persentasi ini menunjukkan bahwa ketiga faktor ini merupakan faktor yang dominan memengaruhi terjadi kesenjangan anggaran pada pelaksanaan anggaran belanja daerah provinsi.

Namun demikian apabila ketiga faktor tersebut dianalisis secara parsial terhadap kesenjangan anggaran, maka hasilnya menunjukkan bahwa hanya faktor informasi asimetris yang memengaruhi terjadinya kesenjangan anggaran tersebut. Kedua variabel lainnya, yaitu pertumbuhan anggaran dan partisipasi anggaran tidak terbukti memengaruhi terjadinya kesenjangan anggaran.

\subsection{Saran}

Dari hasil penelitian ini, peneliti ingin memberikan beberapa saran sebagai berikut:

1) Pemerintah Pusat dan Pemerintah Daerah harus dapat memberikan perhatian lebih dalam pengelolaan keuangan daerah, khususnya bagi daerah yang memiliki anggaran belanja yang besar. Hal ini perlu dilakukan untuk menghindari terjadinya kesenjangan anggaran yang disebabkan oleh "kolaborasi" faktor pertumbuhan anggaran, partisipasi anggaran, dan informasi asimetris.

2) Untuk mencegah terjadinya asimetris informasi yang dapat memengaruhi terjadinya kesenjangan anggaran, maka pemerintah daerah harus membudayakan kegiatan curah informasi (sharing information) yang dilakukan oleh para pegawai dari semua level baik atasan maupun bawahan agar mereka memiliki informasi yang sama, khususnya yang terkait dengan kegiatan penyusunan dan pelaksanaan anggaran.

3) Pemerintah Daerah diharapkan melakukan pengawasan internal secara efektif khususnya yang terkait dengan kegiatan penyusunan anggaran dan pelaksanaan anggaran untuk menghindari terjadinya kesenjangan anggaran.

4) Pemerintah Pusat dapat menginstruksikan kepada Pemerintah Daerah untuk memberikan laporan monitoring realisasi anggaran daerah secara berkala dan akurat. Hal ini perlu dilakukan agar pemerintah pusat dapat ikut berpartisipasi dalam mengurangi terjadinya kesenjangan anggaran pada belanja daerah.

5) Pemerintah Pusat dapat memberikan reward kepada Pemerintah Daerah atas prestasi kinerja pengelolaan keuangan yang dilakukannya, khususnya pada Pemerintah Daerah yang memiliki kesenjangan anggaran rendah. Sebaliknya, Pemerintah Pusat harus berani memberikan punishment kepada Pemerintah Daerah yang memiliki kesenjangan anggaran tinggi.

\section{IMPLIKASI DAN KETERBATASAN}

Implikasi dari hasil penelitian yang telah dilakukan adalah sebagai berikut.

1) Penelitian selanjutnya dapat menggunakan periode tahun yang lebih lama, misalnya 10 tahun atau lebih sehingga data penelitian yang diolah menjadi lebih banyak.

2) Penelitian selanjutnya dapat menggunakan objek penelitian yang lebih sempit dan fokus terhadap pemerintah kota, pemerintah kabupaten, atau pemerintah desa sehingga dapat diketahui apakah fenomena kesenjangan anggaran juga terjadi pada satuan pemerintahan tersebut.

3) Penelitian selanjutnya dapat menggunakan faktor atau variabel lain yang dapat mempengaruhi terjadinya kesenjangan anggaran yang belum diteliti dalam penelitian ini.

4) Penelitian selanjutnya dapat pula menggunakan model penelitian yang berbeda dan alat analisis yang berbeda dengan penelitian ini.

5) Keterbatasan dalam penelitian ini adalah 
penggunaan model penelitian yang sederhana, yaitu model regresi berganda. Apabila ada model lain yang lebih tepat, maka mungkin saja hasil kesimpulannya dapat berbeda dengan penelitian ini.

\section{DAFTAR PUSTAKA}

\section{Buku dan Jurnal Ilmiah}

Bitner, L.N. (2005). Earnings Management: How to Identify Contributing Factors. Hein Online Rev. 25.

Bradshaw, John H., Chris Hunt, Joanne Hills, dan Bhagwan S. Khanna. (2007). Can Budgetary slack Still Prevail within New Zealand's New Public Management?. Working Paper Series No. 53.

Dunk, Alan S. (1997). The Incidence of Budgetary Slack: A Field Study Exploration. Accounting, Auditing \& Accountability Journal Vol. 10: 649-664.

Ghozali, Imam. (2006). Aplikasi analisis multivariate dengan program SPSS. Semarang: Badan Penerbit Universitas Diponegoro.

-----------. (2011). Aplikasi analisis multivariate dengan program IBM SPSS 19. Semarang: Badan Penerbit Universitas Diponegoro.

(2016). Aplikasi analisis multivariate dengan program IBM SPSS 21. Semarang: Badan Penerbit Universitas Diponegoro.

Iqbal, Muhammad. (2015). Pengolahan Data dengan Regresi Linear Berganda (dengan SPSS). Jakarta: Perbanas Institute.

Jaya, M. Faruq Dwi. (2013). The Effects of Budget Participation, Asymmetric Information, Budget Emphasis, and Organizational Commitment on Budgetary Slack in Pemerintah Kota Pasuruan. Skripsi. Malang: Universitas Brawijaya.

Juanda, Bambang. (2009). Metodologi Penelitian Ekonomi dan Bisnis. Bogor: IPB Press.

Kartika, Andi. (2010). Pengaruh Komitmen Organisasi dan Ketidakpastian Lingkungan dalam Hubungan antara Partisipasi Anggaran dengan Senjangan Anggaran (Studi Empirik pada Rumah Sakit Swasta di Kota Semarang). Kajian Akuntansi Vol. 2 (1): 39-60.

Merchant, Kenneth A. (1985). Budgeting and the Propensity to Create Budgetary Slack. Accounting, Organizations, and Society Vol. 10 (2): $201-210$.

Merchant, Kenneth A. dan Wim A. Van der Stede. (2014). Sistem Pengendalian Manajemen: Pengukuran Kinerja, Evaluasi dan Insentif. Jakarta: Salemba Empat.
Nazir, Moh. (2005). Metode Penelitian. Jawa Barat: Ghalia Indonesia.

Onsi, Mohamed. (1973). Factor Analysis of Behavioral Variables Affecting Budgetary Slack. The Accounting Review Vol. 48 (3): 535-548.

Riadi, Edi. (2016). Statistika Penelitian (analisis manual dan IBM SPSS). Yogyakarta: CV Andi Offset.

Rukmana, Paingga. (2013). Pengaruh Partisipasi Anggaran dan Informasi Asimetris Pada Timbulnya Budget Slack (Studi Empiris Pada Pemerintah Daerah Kota Padang). Skripsi. Padang: Universitas Negeri Padang.

Sarwono, Jonathan. (2012). Metode Riset Skripsi Pendekatan Kuantitatif (Menggunakan Prosedur SPSS). Jakarta: Gramedia.

Sekaran, Uma. (2007). Metode Penelitian Untuk Bisnis. Jakarta: Penerbit Salemba Empat.

Siagian, Pramela Augustina. (2009). Flypaper Effect pada Pendapatan Asli Daerah (PAD) dan Dana Alokasi Umum (DAU) terhadap Belanja Daerah pada Pemerintahan Kabupaten/Kota di Provinsi Sumatera Utara. Skripsi. Sumatera Utara: Universitas Sumatera Utara.

Tjahjanti, Rosalia Dwi Fadma. (2004). Pengaruh Partisipasi Penyusunan Anggaran, Komitmen Organisasi, Keterlibatan Kerja, dan Ketidakpastian Lingkungan terhadap Senjangan Anggaran (Studi Empiris pada Industri Manufaktur dan Non-Manufaktur di Jawa Tengah). Tesis. Semarang: Universitas Diponegoro.

Widarjono, Agus. (2010). Analisis Statistika Multivariat Terapan. Yogyakarta: STIM YKPN.

Wiratama, Prama. (2016). Analisis Pengaruh Pertumbuhan Anggaran, Partisipasi Anggaran dan Asimetri Informasi terhadap Budgetary Slack pada Instansi Pemerintah Pusat Periode 2005-2014. Skripsi. Tangerang Selatan: Politeknik Keuangan Negara STAN.

Young, S. (1985). Participative Budgeting: The Effect of Risk Aversion and Asymmetric Information on Budgetary Slack. Journal of Accounting Research Vol. 23 (2): 829-842.

\section{Dokumen Negara}

Undang-Undang Republik Indonesia Nomor 32 Tahun 2004 tentang Pemerintahan Daerah.

Undang-Undang Republik Indonesia Nomor 33 Tahun 2004 tentang Perimbangan Keuangan.

Peraturan Pemerintah Republik Indonesia Nomor 55 Tahun 2005 tentang Dana Perimbangan. 
Peraturan Pemerintah Republik Indonesia Nomor 56 Tahun 2005 tentang Sistem Informasi Keuangan Daerah.

Peraturan Pemerintah Republik Indonesia Nomor 58 Tahun 2005 tentang Pengelolaan Keuangan Daerah.

Peraturan Pemerintah Republik Indonesia Nomor 65 Tahun 2010 tentang Perubahan atas Peraturan Pemerintah Nomor 56 Tahun 2005 tentang Sistem Informasi Keuangan Daerah.

Peraturan Menteri Dalam Negeri Nomor 13 Tahun 2006 tentang Pedoman Pengelolaan Keuangan Daerah.

Peraturan Menteri Keuangan Nomor 4 Tahun 2011 tentang Tata Cara Penyampaian Informasi Keuangan Daerah.

\section{Media dalam Jaringan}

Budidarma. 2011. Anggaran Pendapatan dan Belanja Daerah (APBD). http://budidarma.com/anggaran-pendapatan -dan-belanja-daerah-apbd/ (diakses 29 Desember 2017).

Direktorat Jenderal Perimbangan Keuangan. 2017. Data Keuangan Daerah. http://www.djpk.depkeu.go.id/?page_id=316 (diakses 26 November 2017).

Direktorat Jenderal Perimbangan Keuangan. 2017. Review Data Keuangan Daerah. http://www.djpk.depkeu.go.id/?page_id=325 (diakses 26 November 2017).

Raharjo, Sahid. 2017. Cara Mengatasi Masalah Autokorelasi dengan Uji Run Test Dalam SPSS. http://www.spssindonesia.com/2017/03/aut okorelasi-dengan-uji-run-test-spss.html (diakses 21 Desember 2017) 
